\title{
Differences in Academic Performance between Elementary Charter Schools and Traditional Public Schools
}

\author{
Martha L. Escalante and John R. Slate \\ Department of Educational Leadership, Sam Houston State University, Huntsville, TX, USA \\ Email: profslate@aol.com
}

\begin{abstract}
In this study, the degree to which differences were present in reading for Grade 3 students; in reading and writing for Grade 4 students; and in reading and science for Grade 5 students between charter and traditional elementary public schools in Texas was determined. Participants in this study were Grades 3, 4, and 5 students who took the 2015 State of Texas Assessments of Academic Readiness Reading, Writing, and Science tests. Grade 3, 4, and 5 students who were enrolled in traditional public schools had statistically significantly higher reading, mathematics, writing, and science scores than did students enrolled in charter schools. Implications of these results are provided.
\end{abstract}

Keywords: Charter school, traditional public school, State of Texas Assessment of Academic Readiness tests, reading, mathematics, elementary school

\section{Introduction}

The Charter School Program started in Minnesota in 1991 as an experiment to finance private schools. By 2013, over 2 million students were enrolled in charter schools in the United States (Flaker, 2014). According to the U.S. Department of Education (2015), "charter schools are public schools that operate with freedom from many of the local and state regulations that apply to traditional public schools" (School Choices for Parents section, para. 3). As such, charter schools have different characteristics from traditional public schools. Flaker (2014) identified the following ones: charter schools receive per-student funds from the government, do not charge tuition, and follow a lottery system for student admission.

According to the Texas Education Agency (2016a), in the 2014-2015 school year 5,232,065 students were enrolled in Texas public schools. Of this number, Texas had 616 open enrollment charter school campuses present in which 228,153 students were enrolled. The total student enrollment in charter school increased by $244.9 \%$ compared to the 2004-2005 student enrollment that consisted of 66,160 students. Since then, the number of charter schools has grown tremendously with the authorization of the Texas legislature in 1995. In a study conducted by the Texas Center for Educational Research (2006), when compared to traditional public school, charter schools had a higher percentage of Black students (37\% versus 14\%), a lower percentage of White students (18\% versus $38 \%$ ), and a lower percentage of Hispanics ( $43 \%$ versus $45 \%$ ). In comparison to Texas traditional public schools, charter schools had a higher percentage of students who were economically disadvantaged ( $68 \%$ versus $55 \%$ ), a lower percentage of English Language Learners (11\% versus 16\%), and about an equal percentage of students who were receiving special education services (13\% versus $12 \%$ ). Conversely, these percentages have changed and in the 2014-2015 school year, the number of Black students enrolled in openenrollment charter schools decreased, whereas the number of Hispanic students increased. Hispanics represented the largest percentage of total enrollment in open-enrollment charter schools (57.8\%), followed by Black (20.1\%), White (15.6\%), Asian (4.5\%), and multiracial (1.6\%) students. The percentage of students who were identified as economically disadvantaged was $69.1 \%$, and $21.6 \%$ were English Language Learners.

Penning and Slate (2011) analyzed the demographics, funding, and academics of charter schools in Texas. They confirmed that charter schools serve a higher number of minority students than traditional public schools. In regard to funding, the state gives a higher percentage to charter schools as compared to traditional public schools; yet, the total revenue of charter schools is less than the one from traditional public schools because charter schools are not allowed to receive local taxes. Based on data from the Texas Education Agency, Penning and Slate (2011) concluded that charter schools' academic 
performance was not better than traditional public schools.

As reported by the Texas Education Agency (2016a), most charter schools in Texas are under the open enrollment category, this kind of charter schools are also expanding in the rest of the country. Weiler and Vogel (2015) examined the registration process followed by charter schools in Colorado to assess if this process was accessible to all students. Results were that charter schools' registration system was not accessible to all students. The use of the website and a required parent meeting previous to registration were some of the barriers identified in this study due to not all parents having access to the internet or not being able to attend the parent meeting. Another barrier identified by Weiler and Vogel (2015) was the lottery system followed by charter schools, as families were not ready to transfer schools if the opening occurred in the middle of the school year. The fee requirements were no different from the ones of traditional public schools. In regard to parent commitment, $39 \%$ of the charter schools did require a specific amount of parent volunteer hours, which could be difficult to do for low-income parents that have tight work schedules. Weiler and Vogel (2015) concluded that the waiting list was unclear and the lottery system was not uniform among all charter schools. One recommendation stated by the researchers was for charter schools to follow the same registration requirements as the ones followed by traditional public schools.

The level of efficiency of charter schools was analyzed by Flaker (2014), who compared academic performance and per-student spending in charter and traditional public schools. Flaker (2014) examined reading and mathematics testing data and per-pupil spending for all Grade 8 students enrolled in charter and traditional public schools in Massachusetts. Charter schools outperformed traditional public schools in reading and mathematics, with a difference of $18 \%$. The difference was more noticeable in urban areas where charter schools obtained $31 \%$ and $37 \%$ higher scores in reading and mathematics respectively. Charter schools also demonstrated more efficiency than traditional public schools at spending fewer dollars per student and obtaining better testing scores in reading and mathematics. Differences in academic performance between charter and traditional public schools were analyzed by Kindzierski, Mhammed, Wallace, and Lesh (2013). In their study conducted in New York, charter schools outperformed traditional public schools in Grades 3, 4, and 5, however, test scores decreased in the upper grade levels. In contrast, the traditional public schools were consistent across grade levels in their student academic performance. Kindzierski et al. (2013) suggested further studies to determine the inconsistency with the charter school scores and recommended that charter school administrators emphasize the use of data driven instruction.

In an intent to elucidate if charter schools differed from traditional schools on expenditures, Arsen and $\mathrm{Ni}$ (2012) evaluated the spending and resources allocation of charter schools by analyzing 2007-2008 financial data from the State of Michigan. Traditional public schools and charter schools had similar revenues, although charter schools spent less on instruction and more on administration in comparison to traditional public schools. Arsen and Ni (2012) also detailed that established charter schools spent more on instruction than the new charter schools. One of the conclusions was that the difference on administration expenses could be related to having fewer students with disabilities receiving special education services than traditional public schools.

\subsection{Purpose}

The purpose of this study was to determine whether differences were present in reading performance between charter and traditional elementary public schools for Grade 3 students in Texas. A second purpose was to ascertain whether Grade 4 students differed in their reading and writing skills by school type. A third purpose was to determine for Grade 5 students the extent to which differences were present in reading and science performance between charter and traditional public schools. A final purpose was to ascertain the degree to which consistencies were present in student academic performance between traditional and charter elementary schools.

\section{$2 \quad$ Background}

The number of charter schools has grown substantially in the state of Texas since their authorization by the legislature in 1995 (Texas Education Agency, 2016a). Among the differences between charter schools 
and traditional public schools the following can be highlighted: charter schools can decide on their own registration process (Weiler \& Vogel, 2015) and charter schools operate with freedom from local and state regulations imposed to traditional public schools (U.S Department of Education, 2015). With the increase on the level of rigor of the state assessments, parents are seeking for alternatives, other than traditional public schools, that could help their children to succeed. Although charter schools seem to be increasing in their popularity, limited research is present on their effectiveness on academic achievement success. Are charter schools a viable option? Do they outperform traditional public schools?

\subsection{Significance of the Study}

Even though the Texas legislature approved the implementation of charter schools about 20 years ago, limited research has been conducted in regard to their operations and their student academic performance. By providing comparison data on the academic performance of charter and traditional public schools, these results may be useful to parents when deciding where to enroll their children. Results may also help charter schools design intervention programs that can reduce the academic gaps between this school system and traditional public schools.

\subsection{Research Questions}

The following research questions were addressed in this empirical investigation: (a) What is the difference in reading performance as a function of school type for Grade 3 students in Texas?; (b) What is the difference in reading performance as a function of school type for Grade 4 students in Texas?; (c) What is the difference in writing performance as a function of school type for Grade 4 students in Texas?; (d) What is the difference in reading performance as a school type for Grade 5 students in Texas?; and (e) What is the difference in science performance as a school type for Grade 5 students in Texas?

\section{Method}

\subsection{Participants}

Participants in this study were students in Grades 3, 4, and 5 who took the 2015 State of Texas Assessments of Academic Readiness (STAAR) Reading, Writing, and Science tests. The dataset was downloaded from the Texas Education Agency website. Of the 20,920 campuses who were included for this study, 1,331 were charter schools, whereas 19,589 were traditional public schools.

\subsection{Instrumentation and Procedures}

Data were obtained from the 2015 Texas Academic Performance Report database, and then imported into the Statistical Package for Social Sciences (SPSS) software program. The school type was determined as the independent variable, whereas the STAAR Reading, Writing, and Science test scores represented the dependent variables. The focus of this study was to determine differences in academic performance between charter schools and traditional public schools. The term charter school refers to schools that are governed by a group or organization under a legislative contract (or charter) with the state or jurisdiction. The charter exempts the school from certain state or local rules and regulations. Traditional Public Schools are schools that follow state guidelines. They operate with the help of tax dollars, and are divided into grades and governed by school districts. This investigation was based on the STAAR scores of students in Grades 3, 4, and 5. The State of Texas Assessments of Academic Readiness (STAAR) is the state testing program that was implemented in the 2011-2012 school year. The STAAR is an assessment program designed to measure the extent to which students have learned and are able to apply the knowledge and skills defined in the state-mandated curriculum standards, the Texas Essential Knowledge and Skills (Texas Education Agency, 2016b). For detailed information about the score reliabilities and score validities of the STAAR tests, readers are referred to the Texas Education Agency website. 


\section{$4 \quad$ Results}

Prior to conducting an inferential statistical procedure to determine whether statistically significant differences were present in academic performance between charter and traditional elementary public schools in Texas for students in Grades 3, 4, and 5, checks were conducted to determine the extent on which these data were normally distributed. An examination of the standardized skewness coefficient (i.e., the skewness value divided by the standard error of the skewness) and standardized kurtosis coefficient (i.e., the kurtosis value divided by the standard error of the kurtosis), revealed one of them was within the limits of normality, +/- 3 (Onwuegbuzie \& Daniel, 2002), whereas the other four values revealed serious departures from normality. Accordingly, a parametric independent samples $t$-test was conducted to analyze the first research question that contained data that were within the range of normality, and nonparametric independent samples $t$-tests were utilized to answer research questions 2 , 3,4 and 5 . Independent samples $t$-tests are an appropriate inferential statistical procedure to calculate when the independent variable (i.e., school type) is dichotomous and the depiendent variable (i.e., STAAR scores) are at the interval/ratio level of measurement (Slate \& Rojas-LeBouef, 2011).

For the first research question, a parametric independent samples $t$-test was used to compare Grade 3 students' reading performance between charter schools and traditional public schools in Texas. A statistically significant difference, $t(304.93)=4.67, p<.001$, was present. This difference represented a small effect size (Cohen's $d$ ) of 0.31 (Cohen, 1988). Grade 3 students in traditionall public schools had a statistically significantly higher average reading passing rate, $4.54 \%$ higher, than Grade 3 students in charter schools. Descriptive statistics for this analysis are revealed in Table 1 and are depicted in Figure 1. As shown in Figure 1, STAAR Reading scores were higher in traditional public schools than in charter schools.

Table 1. Descriptive statistics for grade 3 STAAR reading performance by school type in Texas

\begin{tabular}{l|c|c|c}
\hline School Type & $n$ of schools & $M$ & $S D$ \\
\hline Charter & 278 & 72.99 & 15.82 \\
\hline Traditional Public School & 4,050 & 77.53 & 13.40 \\
\hline
\end{tabular}

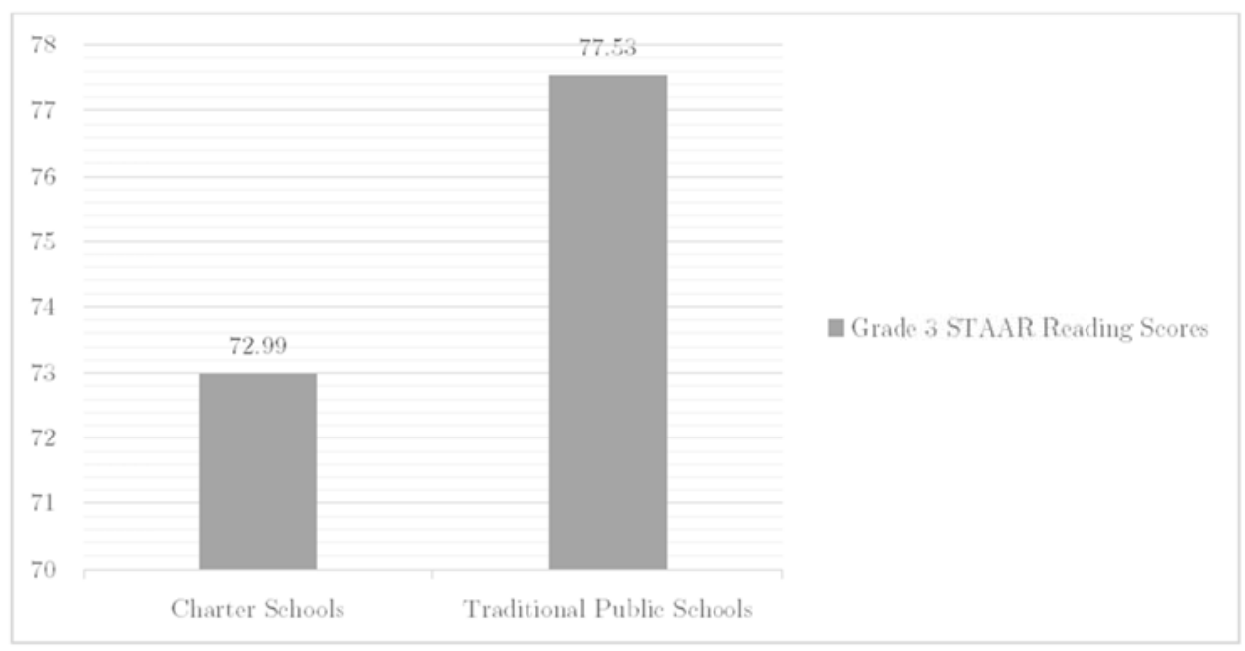

Figure 1. Grade 3 STAAR reading performance for students enrolled at charter schools and traditional public schools.

For the second research question regarding reading performance as a function of school type for Grade 4 students in Texas, because reading scores were not normally distributed, a nonparametric (i.e., MannWhitney's $U$ ) independent samples $t$-test was used. The Mann-Whitney $U$ test revealed a statistically significant difference in the reading performance of Grade 4 students as a function of school type, $U=$ 
570913.50, $p=.023$, Cohen's $d$ of 0.17. Using Cohen's (1988) criteria, this finding represented a small effect size. As revealed in Table 2, Grade 4 students in traditional public schools had a higher average STAAR Reading test passing rate, $2.67 \%$ higher, than Grade 4 students in charter schools. Depicted in Figure 2 are the results for this analysis. Similar to the results for Grade 3 students, STAAR Reading scores were higher in traditional public schools than in charter schools.

Table 2. Descriptive statistics for grade 4 STAAR reading performance by school type in Texas

\begin{tabular}{l|c|c|c}
\hline School Type & $n$ of schools & $M$ & $S D$ \\
\hline Charter & 262 & 71.10 & 16.42 \\
\hline Traditional Public School & 4,021 & 73.77 & 14.95 \\
\hline
\end{tabular}

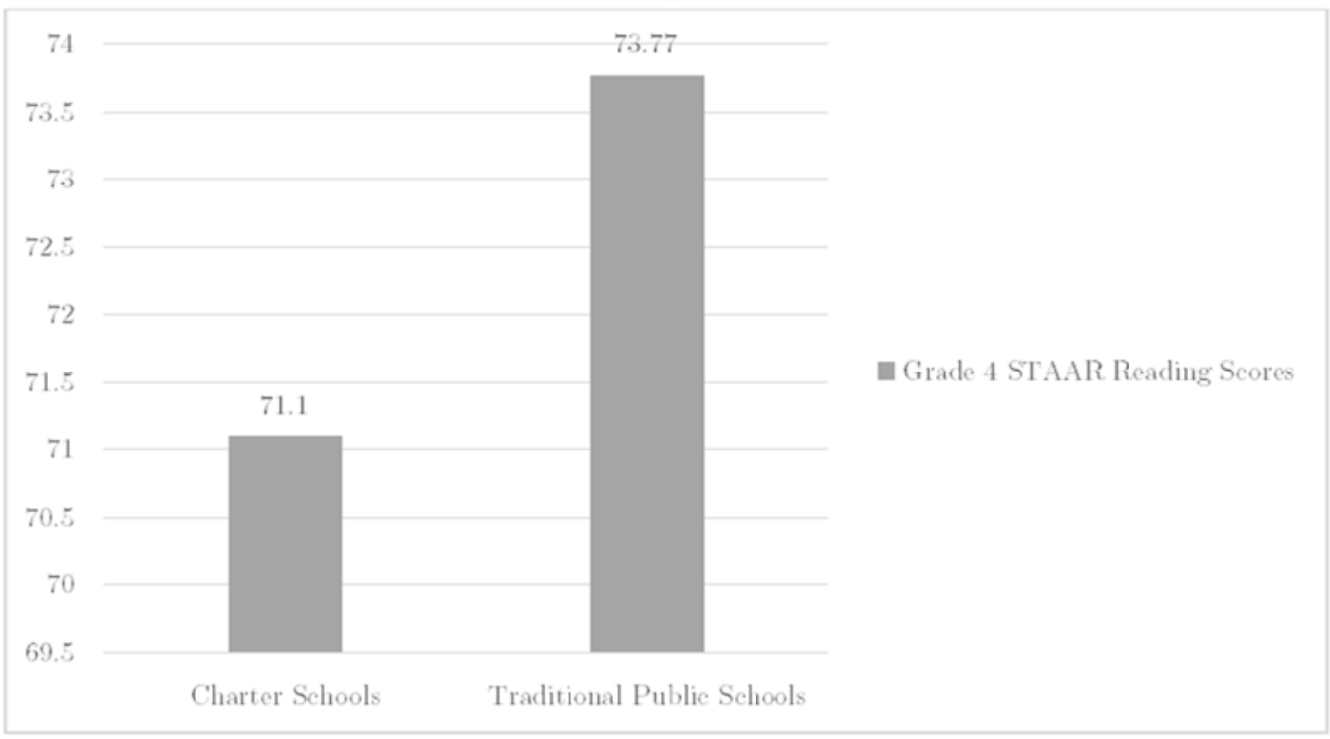

Figure 2. Grade 4 STAAR reading performance for students enrolled at charter schools and traditional public schools.

For the third research question, a nonparametric independent samples $t$-test was used to determine whether writing performance differed as a function of school type for Grade 4 students in Texas. The Mann-Whitney $U$ test did not yield a statistically significant difference between Grade 4 students in charter and traditional public schools in Texas, $U=565063.50, p=.08$. Grade 4 students in traditional and in charter schools had similar passing rates on the STAAR Writing test. Descriptive statistics for this analysis are delineated in Table 3 and are depicted in Figure 3. As shown in Figure 3, traditional public schools had a slightly higher score than charter schools on the STAAR Writing test.

Table 3. Descriptive statistics for grade 4 STAAR writing performance by school type in Texas

\begin{tabular}{l|c|c|c}
\hline School Type & $n$ of schools & $M$ & $S D$ \\
\hline Charter & 265 & 68.10 & 17.28 \\
\hline Traditional Public School & 4,011 & 70.07 & 15.53 \\
\hline
\end{tabular}




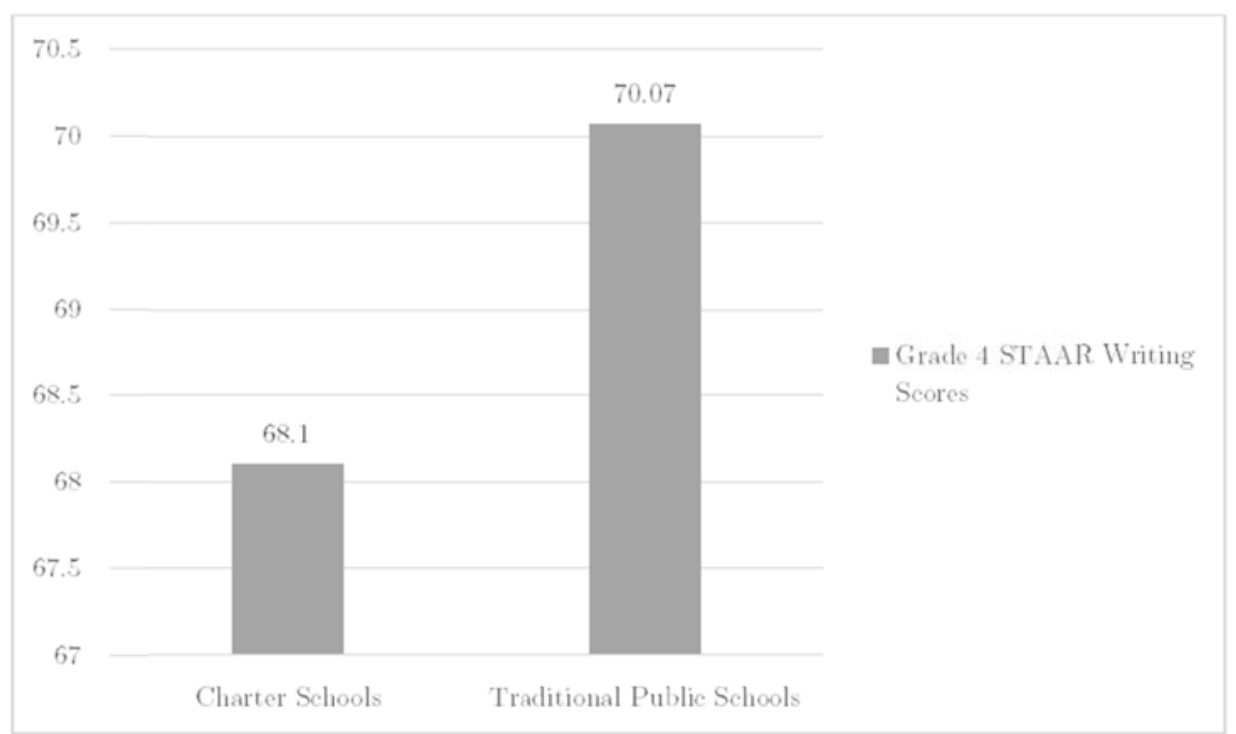

Figure 3. Grade 4 STAAR writing performance for students enrolled at charter schools and traditional public schools.

A nonparametric independent samples $t$-test was used for the fourth research question on the reading performance of Grade 5 students in Texas as a function of school type. The Manm-Whitney $U$ test did not reveal a statistically significant difference between Grade 5 students in charter and traditional public schools, $U=540565.00, p=.11$. Grade 5 students in traditional and in charter elementary schools had similar passing rates on the STAAR Reading test. Presented in Table 4 are the descriptive statistics for this analysis. Depicted in Figure 4 are the results for this analysis. Sinnilar to the results for Grade 4 students, the scores on the STAAR Reading test were slightly higher in traditional public schools.

Table 4. Descriptive statistics for grade 5 STAAR reading performance by school type in Texas

\begin{tabular}{l|c|c|c}
\hline School Type & $n$ of schools & $M$ & $S D$ \\
\hline Charter & 271 & 85.54 & 11.98 \\
\hline Traditional Public School & 3,772 & 87.27 & 10.04 \\
\hline
\end{tabular}

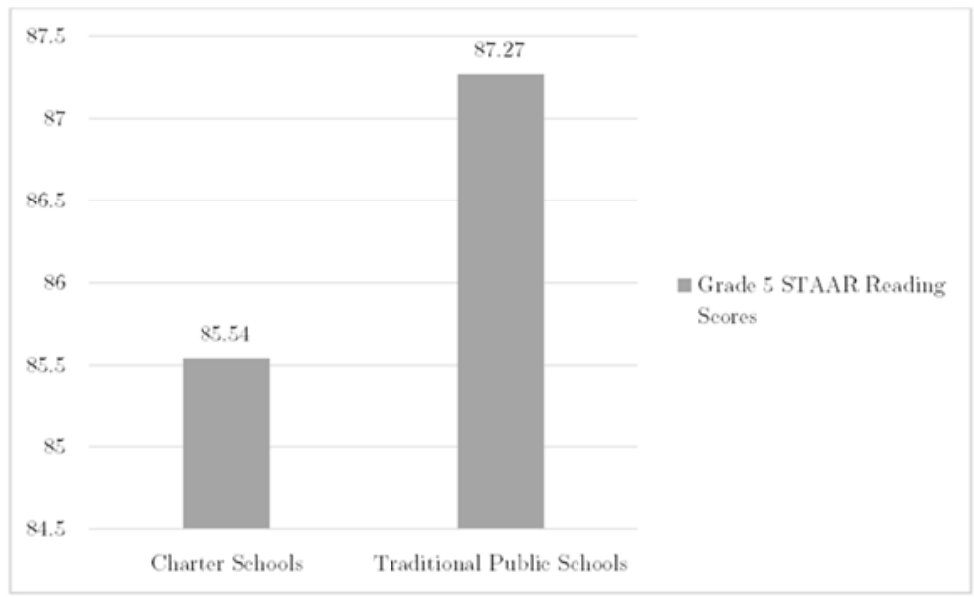

Figure 4. Grade 5 STAAR reading performance for students enrolled at charter schools and traditional public schools. 
For the last research question, a nonparametric independent samples $t$-test was used to compare the STAAR science performance as a function of school type for Grade 5 students. The Mann-Whitney $U$ test revealed a statistically significant difference, $U=568818.00, p<.001$, Cohen's $d$ of 0.53 . Using Cohen's (1988) criteria, this finding represented a moderate effect size. Grade 5 students in traditional public schools had a higher average passing rate, $6.02 \%$ higher, than did charter school Grade 5 students on the STAAR Science exams. Descriptive statistics for this analysis are delineated in Table 5 and are depicted in Figure 5. As shown in Figure 5, STAAR Science scores were higher in traditional public schools than charter schools.

Table 5. Descriptive statistics for grade 5 STAAR science performance by school type in Texas

\begin{tabular}{l|c|c|c}
\hline School Type & $n$ of schools & $M$ & $S D$ \\
\hline Charter & 255 & 65.46 & 17.59 \\
\hline Traditional Public School & 3,735 & 71.48 & 16.18 \\
\hline
\end{tabular}

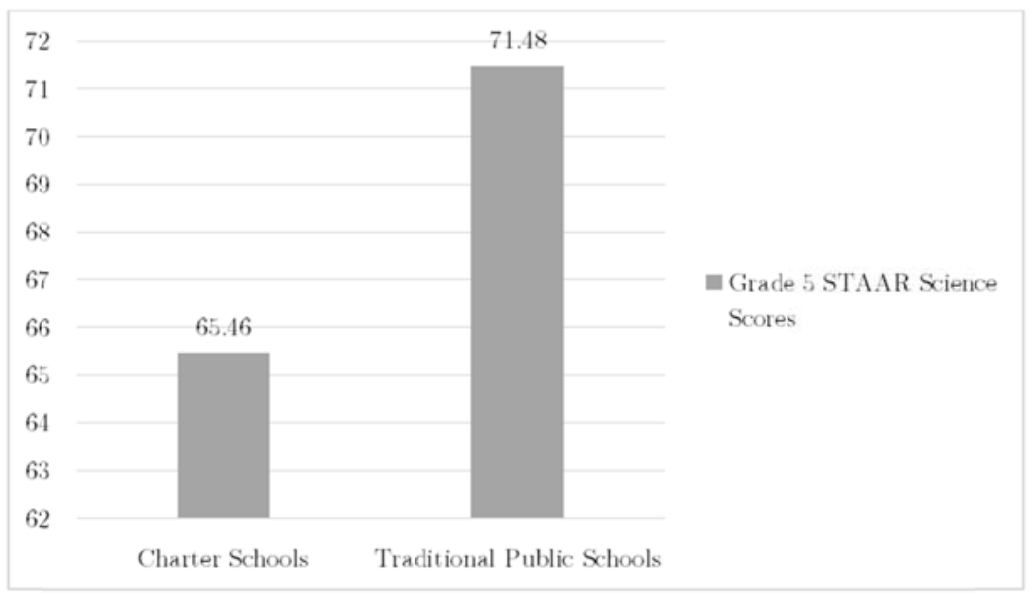

Figure 5. Grade 5 STAAR science performance for students enrolled at charter schools and traditional public schools.

\section{Discussion}

Since their creation in 1991, over 2 million students were enrolled in charter schools in the United States (Flaker, 2014). In Texas, the total student enrollment in charter schools increased by $244.9 \%$ from $2004-$ 2005 to 2014-2015 (Texas Education Agency, 2016a). Despite their rapid expansion, limited research has been conducted on the academic performance of charter schools.

The focus of this study was on the academic performance of charter and traditional elementary public school students in Grades 3, 4 and 5 in Texas using STAAR test scores. Students who were enrolled in traditional elementary public schools outperformed students who were enrolled in charter elementary schools in Grade 3 for reading and Grade 5 for science. Passing rates were similar for students in Grades 4 and 5 at the two different elementary schools. Penning and Slate (2011) noted similar results in an analysis conducted on charter schools in Texas, concluding that charter schools' academic performance was not considerably better than traditional public schools.

Lest readers overgeneralize from these results, several cautions are in order. First, this study was limited to aggregated state level data on charter and traditional elementary public schools in Texas. Data on only Grade 3, 4, and 5 students were analyzed. The data analyzed in this study were obtained from the 2015 STAAR scores. Although the results obtained herein were congruent with the existing literature that charter schools do not have higher levels of academic achievement than traditional schools, readers are urged to be cautious in any generalizations they make from this study. 


\section{References}

1. Arsen, D., \& Ni, Y. (2012). Is administration leaner in charter schools? Resource allocation in charter and traditional public schools. Education Policy Analysis Archives, 20(31), 1-19. Retrieved from http://epaa.asu.edu/ojs/article/view/1016

2. Cohen, J. (1988). Statistical power analysis for the behavioral sciences (2nd ed.). Hillsdale, NJ: Lawrence Erlbaum.

3. Flaker, A. (2014). School management and efficiency: An assessment of charter vs. traditional public schools. International Journal of Educational Development, 39, 235-246. doi:10.1016/j.ijedudev.2014.07.001

4. Kindzierski, C. M., Mhammed, A. A., Wallace, N., \& Lesh, C. (2013). State assessments: Does a charter school truly demonstrate higher proficiency than its public counterpart? Current Issues in Education, 16(2), 1-12. Retrieved from https://cie.asu.edu/ojs/index.php/cieatasu/article/view/1072

5. Onwuegbuzie, A. J., \& Daniel, L. G. (2002). Uses and misuses of the correlation coefficient. Research in the Schools, 9(1), 73-90.

6. Penning, F., \& Slate, J. R., (2011). Charter schools in Texas: An overview. International Journal of Educational Leadership Preparation, 6(3). Retrieved from http://files.eric.ed.gov/fulltext/EJ974247.pdf

7. Slate, J. R., \& Rojas-LeBouef, A. (2011). Calculating basic statistical procedures in SPSS: A self-help and practical guide to preparing theses, dissertations, and manuscripts. Ypsilanti, MI: NCPEA Press.

8. Texas Center for Educational Research. (2006). Texas Open-Enrollment Charter School Revenue Supplement to the 2003-2204 Evaluation. Austin, TX: Texas Center for Educational Research.

9. Texas Education Agency. (2016a). Enrollment in Texas public schools, 2014-15. (Document No. GE16 60109$).$ Austin TX: Author. Retrieved from http://www.tea.texas.gov/acctres/enroll_index.html

10.Texas Education Agency. (2016b). Student Assessment Division. Retrieved from http://tea.texas.gov/student.assessment/staar/

11.U.S. Department of Education. (2015). School choices for parents. Retrieved from http://www2.ed.gov/parents/schools/choice/definitions.html

12.Weiler, S. C., \& Vogel, L. R. (2015). Charter school barriers: Do enrollment requirements limit student access to charter schools? Equity \& Excellence in Education, 48(1), 36-48. doi:10.1080/10665684.2015.992288 